\title{
Phenotypic and genotypic evaluation of adherence and biofilm development in Candida albicans respiratory tract isolates from hospitalized patients
}

\author{
Omar Sadik ${ }^{1,2}$, Lia Mara Ditu ${ }^{1,2}$, Irina Gheorghe ${ }^{1,2^{*}}$, Alina Maria Holban ${ }^{1,2}$, \\ Carmen Curutiu ${ }^{1,2}$, Gratiela Gradisteanu Parcalabioru ${ }^{1,2}$, Ionela Avram ${ }^{1,2}$, Otilia \\ Banu $^{3}$, Othman Al-mahdawy ${ }^{1,2}$, Dunya A. Alkurjia ${ }^{1,2}$, Mariana Carmen Chifiriuc ${ }^{1,2}$ \\ 1. University of Bucharest, Faculty of Biology, Bucharest, Romania \\ 2. Research Institute of the University of Bucharest(ICUB), Bucharest, Romania \\ 3. Emergency Institute of Cardiovascular Diseases "Prof. Dr. C.C. Iliescu”, Bucharest, Romania
}

\begin{abstract}
In recent years, a significant number of epidemiological variations have been observed for fungal infections. In immunocompromised patients, Candida albicans is crucially involved in invasive infections, mostly originating in respiratory tract colonization. The global rise in candidiasis has led researchers to investigate possible correlations between fungal strains virulence profiles and their pathogenic potential, among the most investigated genes being those involved in adherence and biofilm development. In this study, we established the adherence gene profiles of C. albicans strains isolated from respiratory tract secretions in patients hospitalized for cardiovascular diseases and correlated them with the ability of the respective strains to colonize the epithelial cells and form biofilms on the inert substratum. The strains isolated from the lower respiratory tract exhibited the highest adherence capacity and were intensive biofilm producers. The SAP9, ALS3, ALS5, and ALS6 genes were the most frequently detected. There was a significant association between the presence of $A L S 3$ gene and the cellular substrate colonizing potential of the harboring strains. We also found that the strains expressing SAP9 were more virulent in the phenotypic assays. Detecting the presence of adherence genes from different clinical isolates is a cost-effective tool that would allow researchers to predict the virulence of a certain strain and estimate its potential to adhere to host cells and develop biofilms.
\end{abstract}

Keywords: Candida albicans, adherence genes, adherence to cellular substratum, biofilm

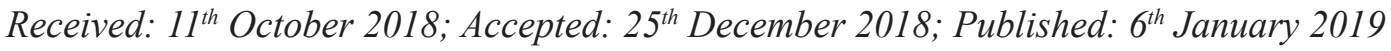

\section{Introduction}

Candida albicans is generally a widespread fungal pathogen that is involved either in superficial or blood-disseminated infections $(1,2)$. Oral Candida spp. is the most widely recognized contaminant found in the elderly or hospitalized patients, causing systemic or mucosal diseases (3-5). The oral colonization with Candida spp. in the elderly is favored by prostheses wearing, poor oral/denture cleaning and low salivation stream (6-9).

\footnotetext{
*Corresponding author: Irina Gheorghe, University of Bucharest, Faculty of Biology, Bucharest, Romania E-mail: IRYNA_84@yahoo.com
} 
The ability of $C$. albicans to form biofilms on both cellular and prosthetic device surfaces increases the severity of the infection. Biofilms are complex, three-dimensional microbial structures encased in an extracellular matrix that are connected to either a biotic or an abiotic surface (10-14). Biofilms decrease the host immune system by an increased microbial resistance to antimicrobial agents $(10,13-15)$ and thus play a significant role in virulence. The $C$. albicans biofilms consist of yeast and hyphae, both of which being indispensable to fungal adherence and subsequent biofilm development (16-19). The increased prevalence of candidiasis worldwide has led to investigations of the possible correlations between adherence genes profiles and the adherence and biofilm development capacity, assessed phenotypically. Recently, the detection of a variety of regulators and effectors that included biofilm formation in C. albicans has increased the understanding of the complex mechanisms concerned with this process [reviewed in (20)]. Various cell wall proteins, including Bcr1, a transcription factor that controls gene expression of cell wall proteins, have been revealed to play important roles in biofilm formation. In addition, Agglutinin-like sequences ( $A L S 1, A L S 3)$, and the hyphal wall protein $1(H W P 1)$ contribute to biofilm formation and maturation (21-23).

Also, a direct correlation between secreted aspartyl proteinase (SAP) production and C. albicans adherence capacity has been highlighted. It was observed that proteolytic C. albicans isolates exhibited a higher capacity of in vitro adherence to human oral epithelial cells compared with isolates that synthesized less proteinase (24). In mice, an isolate that produced higher levels of proteinases also exhibited increased in vivo tissue colonization capacity of the liver, kidneys, and spleen, and led to the death of the mice (25). The majority of the existing studies investigating the C. albicans biofilm production have focused on SAPs. In the anaerobic environments of the root canal systems and periodontal pockets, SAP secretion increases. This observation suggests that the virulence of $C$. albicans is significantly influenced by the concentration of oxygen in the infection site (26). It has been demonstrated that pepstatin, an inhibitor of SAP2 (and probably of SAP1 and SAP3) decreased C. albicans biofilm development capacity with variable efficiency (27). Pepstatin treatment decreased C. albicans adhesion and invasion of human epidermal cells and mucosa $(28,29,30)$.

The EAPl gene (extracellular adhesion protein) encodes a putative cell wall adhesin (31) that contains a signal peptide and a glycosylphosphatidylinositol anchor site; EAPl gene is homologous to other yeast genes that code for cell wall proteins.

Cell surface hydrophobicity (CSH) plays a vital role in $C$. albicans pathogenesis. Hydrophobic cells displayed higher adherence to both epithelial and endothelial cells and to extracellular matrix proteins, as well as greater resistance to phagocytosis (32). CSH varied due to different environmental conditions and growth phases (33).

The aim of the current study was to establish the adherence gene profiles of $C$. albicans isolates from respiratory tract secretions in patients hospitalized for cardiovascular diseases and to correlate them with the ability of the respective isolates to colonize the epithelial cells and to form biofilms on the inert substratum.

\section{Materials and Methods}

\section{Fungal strains}

In this study, we analyzed twenty-nine C. albicans strains isolated from patients admitted for cardiovascular surgery, aged 25-89 years and diagnosed with respiratory tract infections. Nineteen specimens were isolated from sputum and 10 samples from bronchial secretions. None of the patients was dental prosthesis wearer. The C. albicans ATCC10231 was used as reference strain. 
Sabouraud Dextrose Agar (SDA) medium was used to initially isolate the strains, which, subsequently, were biochemically identified using the VITEK II automatic analyzer (bioMérieux), after inoculating Yeast plastic cards (YPC) with the required inoculum suspension. The YBC cards were then incubated at $37^{\circ} \mathrm{C}$ for $24-48 \mathrm{~h}$ and submitted for reading.

\section{Biofilm microtiter assay}

A microtiter plate method was used to assess the ability of $C$. albicans isolates to attach to an inert substratum and to examine the subsequent biofilm production. C. albicans isolates were maintained overnight in Sabouraud broth at $37^{\circ} \mathrm{C}$ and then centrifuged at $150 \mathrm{rpm}$. The cells were collected, washed by using phosphate buffered saline (PBS), and standardized to a density of 1 $\times 10^{7}$ yeast cells $/ \mathrm{ml}$. A volume of $100 \mu 1$ of the yeast cells suspension was added to the wells of a 96-well plate and incubated at $37^{\circ} \mathrm{C}$ for $96 \mathrm{~h}$. After incubation, the liquid content of the wells was discarded, and the wells were washed three times with distilled water in order to remove the non-adherent cells. Then, the cells adherent on the plastic wells were fixed with cold methanol for $5 \mathrm{~min}$ and then stained with crystal violet (CV) solution for $15 \mathrm{~min}(34,35)$. In order to evaluate the stained biofilms, first the wells were examined using an inverted microscope. Then, the biofilm formed on the plastic wells was resuspended with a $33 \%$ acetic acid solution and the optical density of the biofilm cell suspension was determined by measuring the absorbance of the colored suspension at $490 \mathrm{~nm}$ using an enzyme linked immunosorbent assay (ELISA) plate reader, the results being interpreted according to Melo et al. (36). All tests were done in triplicate and biofilm production quantities were reported as the arithmetic mean of absorbance values of the three replicate test. The absorbance values of the negative controls (containing no cells) were subtracted from the values of the test wells to minimize background interference. The biofilm forming intensity was quantified according to their cut-offs by OD value as none absent (unable to form a biofilm), low (when $<\sim \leq 2 \mathrm{x}$ ODc), moderate (when $<\sim \leq 4 \mathrm{x}$ ODc) or high ( $>$ 4x ODc) (37).

\section{Evaluation of the capacity of adherence to HeLa cells}

An adaptation of the Cravioto method was used to determine adherence capacity of each isolate to HeLa cells. The assay was performed as previously described (38). HeLa cells were grown in 6-well plates for $24 \mathrm{~h}$ in Dulbecco's Modified Eagle's Medium (DMEM) involved with antibiotics; after this incubation, the cell monolayers reached $80 \%$ confluence. Wells were washed 3 times with PBS to remove the growth medium. To prepare the fungal suspension, yeast was grown in Sabouraud glucose broth supplemented with $3 \%$ glucose for $48 \mathrm{~h}$ at $37^{\circ} \mathrm{C}$. Cells were centrifuged at $1500 \mathrm{rpm}$ for $10 \mathrm{~min}$, and the pellets were washed with PBS ( $\mathrm{pH} \sim 7.2)$. The cell density in the final suspension was $10^{7}$ colony forming units/ml (using a 0.5 McFarland standard). One $\mathrm{ml}$ of the final fungal suspension was added aseptically above each cellular monolayer. The plates were then incubated at $37^{\circ} \mathrm{C}$ for 2 $\mathrm{h}$ to allow the yeast cells to properly adhere to the cellular surface. Then, the cells were fixed with methanol for 5 min after washing with PBS three times. The wells were stained with a 1:10 Giemsa solution (Merck, Darmstadt, Germany) for $20 \mathrm{~min}$, washed with tap water, used room temperature for drying, examined under microscope (2500 total magnification) with I.O., and then photographed with a Contax camera (supplied with Zeiss microscope). The adherence index (AIn) for each isolate was calculated as the percentage of Hela cell showing adherent fungal cells to the total number of HeLa cells. The average number of fungal cells adhered to one HeLa cell was also calculated. 


\section{Detection of adherence genes}

The total DNA was isolated using the thermolysis method according to the protocol of Zang et al (39). All purified strains were grown on SDA medium at $37^{\circ} \mathrm{C}$ for $24 \mathrm{~h}$. Subsequently, isolated fungal colonies were routinely subcultured in Yeast Nitrogen Base (YNB; BD Diagnostics, Cowley, UK) medium enhanced with glucose $(0.5 \% \mathrm{w} / \mathrm{v})$ overnight at $37{ }^{\circ} \mathrm{C}$, under stirring at $120 \mathrm{rev} / \mathrm{min}$. Cells were harvested by centrifugation at $3000 \mathrm{~g}$ for $10 \mathrm{~min}$ at $4^{\circ} \mathrm{C}$ and the pellet was washed 2 times with $10 \mathrm{~mL}$ PBS ( $\mathrm{pH} 7$ ). The cellular density for each strain was adjusted to $1 \times 10^{7}$ cells $/ \mathrm{ml}$. Pooled biofilms from each collection site were carefully transferred to Eppendorf tubes that contained $1 \mathrm{~mL}$ of reduced transport fluid (RTF). Immediately after collection, the samples from each site were diluted and plated onto SDA medium with chloramphenicol (bioMérieux, Paris, France). The plates were incubated in a reduced oxygen atmosphere $\left(10 \% \mathrm{CO}_{2}\right.$ and $90 \%$ air $)$ for $48 \mathrm{~h}$ at $37^{\circ} \mathrm{C}$. DNA was extracted with slight modifications from a protocol by Nascimento et al. (40). The yeast colonies were suspended in $1 \mathrm{~mL}$ of a solution containing $1 \mathrm{M}$ sorbitol and $125 \mathrm{M}$ ethylenediaminetetraacetic acid (EDTA). This suspension was centrifuged at $13000 \mathrm{~g}$ for $10 \mathrm{~min}$ at $25{ }^{\circ} \mathrm{C}$. The pellet was resuspended in $0.5 \mathrm{~mL}$ lysis solution [ $1 \mathrm{M}$ TrisHCl, $\mathrm{pH}$ 8.0, with $250 \mathrm{mM}$ EDTA and 5\% sodium dodecyl sulfate (SDS)] with $10 \mathrm{~mL}$ of proteinase $\mathrm{K}$ (Invitrogen), and incubated for $1 \mathrm{~h}$ at $65^{\circ} \mathrm{C}$. Subsequently, $500 \mu \mathrm{l}$ of $5 \mathrm{M}$ potassium acetate was added to the mixture and incubated on ice for $2 \mathrm{~h}$. The mixture was centrifuged at $13000 \mathrm{~g}$ for $10 \mathrm{~min}$ at $25^{\circ} \mathrm{C}(40)$. The supernatant was transferred to an Eppendorf tube containing 1 $\mathrm{mL}$ absolute ethanol. The tubes were mixed by inversion centrifuged at $13000 \mathrm{~g}$ for $10 \mathrm{~min}$ at $4^{\circ} \mathrm{C}$. The pellet was washed with $500 \mu \mathrm{l}$ of ice cold $70 \%$ ethanol and then centrifuged at $13000 \mathrm{~g}$ for $10 \mathrm{~min}$ at $4^{\circ} \mathrm{C}$. The final pellet was re-suspended in $0.5 \mathrm{~mL}$ of sterile MilliQ water. The DNA concentration was determined at 260 nm using a spectrophotometer (Genesys 10UV, Rochester, NY, USA). These data were used to prepare a standard with of $100 \mathrm{ng} / \mathrm{ml}$ concentration. The standard was stored for the next PCR reactions at $20^{\circ} \mathrm{C}$. Simplex and multiplex PCR reactions using specific primers were used to identify $C$. albicans adhesion genes (41). A positive control was performed using DNA purified from the $C$. albicans ATCC 10231 reference strain. The GeneAmp PCR system 2400 (Perkin-Elmer-Applied Biosystems) was employed for PCR amplification using the following thermal conditions: $94^{\circ} \mathrm{C}$ for $5 \mathrm{~min}, 35$ cycles of $94{ }^{\circ} \mathrm{C}$ for $30 \mathrm{~s}, 55^{\circ} \mathrm{C}$ for $30 \mathrm{~s}$, and $72^{\circ} \mathrm{C}$ for $30 \mathrm{~s}$, and a final extension at $72^{\circ} \mathrm{C}$ for $10 \mathrm{~min}$. Electrophoresis was used to separate PCR products on $2 \%$ agarose gels using Tris-borate-EDTA running buffer $(\mathrm{pH}$ 8.0). The DNA, including the molecular mass ladder (1000 bp DNA ladder), was stained using a $0.5 \mu \mathrm{g} / \mathrm{ml}$ solution of ethidium bromide. The stained gel was visualized with UV illumination (Pharmacia LKB-MacroVue, San Gabriel, CA, USA).

\section{Statistical analysis}

Statistical analysis was carried out using SPSS version 16.0. For all statistical tests, $\mathrm{P}<0.05$ was considered significant and $\mathrm{P}<0.01$ highly significant. Inferential data analysis was performed to test. The contingency coefficients (C.C.) test was used to determine the correlation of the cause to association tables. The null hypothesis under Ho says that redistribution of the observed frequencies in the created association table through applying the new suggested method using stemleaf technique are randomly distributed (meaningless relationship) versus the alternative hypothesis which says that the contingency coefficient of the association table is meaningful. In addition, under and upper redistribution cutoff 
points were used to create $2 \times 2$ rank association tables and these were applied to the Steam-Leaf plotting technique.

\section{Results}

In this study, we analyzed 29 C. albicans isolates recently isolated from patients aged 25 to 89 years. The majority of the isolates $(65 \%)$ were isolated from lower respiratory tract (bronchial) secretions. We observed no significant difference in isolation rates based on gender (male to female ratio was $1.08, P>0.05$ ) (Table 1 ).
Most of the $C$. albicans isolates from the bronchial secretions exhibited a localized adherence pattern, while the vast majority of sputum strains exhibited an aggregative adherence pattern (Figure 1, Table 1). We observed that the isolated $C$. albicans strains adhered to HeLa cellular substratum with different intensities as revealed by the adherence index values (AIn) that ranged from 70 to $87.7 \%$ (Table 1). Bronchial-derived strains had higher AIn compared to strains isolated from sputum (Table 1).

The majority of isolates from both bronchial and sputum samples developed biofilms on the inert

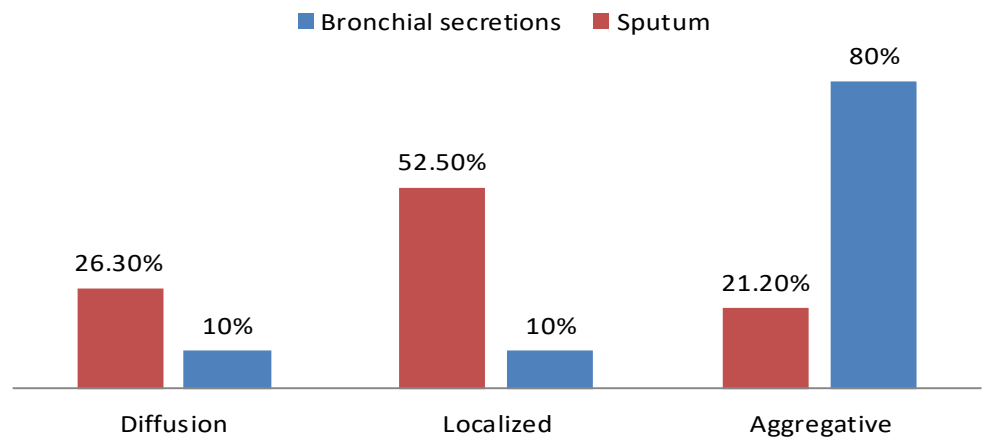

Fig. 1. Adherence patterns (\%) of $C$. albicans strains isolated from sputum and bronchial secretions

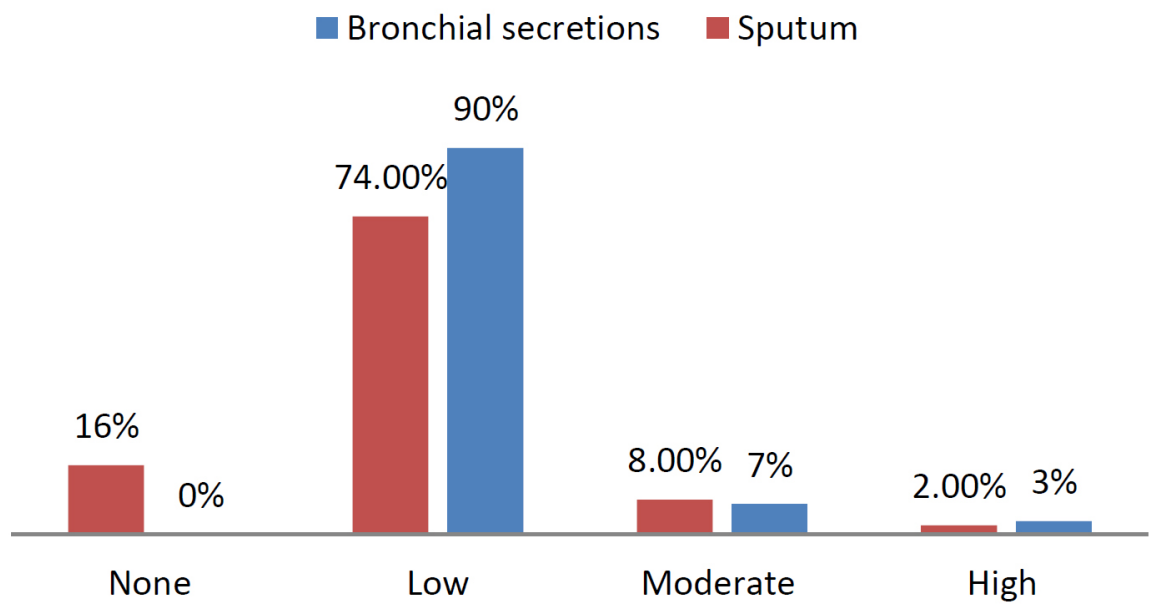

Fig. 2: Distribution of $C$. albicans strains according to source and capacity to develop a biofilm on an inert substratum. The ability to form a biofilm was classified as absent (unable to form a biofilm), low, moderate, or high. 
Table 1. Phenotypic and genotypic features of $C$. albicans isolates

\begin{tabular}{|c|c|c|c|c|c|c|c|c|}
\hline $\begin{array}{l}\text { C. albicans } \\
\text { strain code }\end{array}$ & $\begin{array}{l}\text { Isolation } \\
\text { source }\end{array}$ & Age & Sex & AIn & $\begin{array}{c}\text { Average no. } \\
\text { of yeast cells/ } \\
\text { HeLa cell }\end{array}$ & $\begin{array}{l}\text { Adher- } \\
\text { ence } \\
\text { pattern }\end{array}$ & $\begin{array}{c}\text { Biofilm to } \\
\text { inert sub- } \\
\text { stratum }\end{array}$ & Adherece genes profile \\
\hline 256 & Sputum & 89 & $\mathrm{M}$ & $73.82 \%$ & 8.77 & $\begin{array}{l}\text { Aggrega- } \\
\text { tive }\end{array}$ & None & $\begin{array}{l}A L S 2,3,4,5,6,7,8 \\
S A P 4,5,9,10, E A P 1\end{array}$ \\
\hline 67 & Sputum & 62 & $\mathrm{M}$ & $66.66 \%$ & 5 & Localized & Low & $\begin{array}{c}A L S 1,3,5,6,8 \\
\text { SAP 9, } 10\end{array}$ \\
\hline 154 & Sputum & 39 & $\mathrm{M}$ & $73.98 \%$ & 5.12 & $\begin{array}{l}\text { Aggrega- } \\
\text { tive }\end{array}$ & None & $\begin{array}{c}A L S 1,3,4,6,7,8, S A P \\
5,6,9,10\end{array}$ \\
\hline 175 & Sputum & 85 & M & $65.07 \%$ & 5.8 & $\begin{array}{l}\text { Aggrega- } \\
\text { tive }\end{array}$ & Low & $\begin{array}{c}A L S \text { 1,2,3, } \\
S A P 2,4,5,9,10\end{array}$ \\
\hline 489 & Sputum & 56 & $\mathrm{M}$ & $31.31 \%$ & 2.28 & Localized & Low & $\begin{array}{c}A L S 1,2,3,5,6,7,8, S A P \\
4,6,9,10,\end{array}$ \\
\hline 772 & Sputum & 46 & $\mathrm{~F}$ & $32.73 \%$ & 7.42 & Diffusion & Low & $\begin{array}{c}A L S \text { 3, 5, 6, } \\
\text { SAP 6, } 9\end{array}$ \\
\hline 31 & Sputum & 38 & $\mathrm{~F}$ & $41.29 \%$ & 7.87 & Localized & Low & $\begin{array}{c}A L S 1,2,3,4,5,6,7,8 \\
S A P 4,5,6,9,10, E A P 1\end{array}$ \\
\hline 8159 & Sputum & 49 & M & $28.57 \%$ & 0.7 & Localized & Low & $\begin{array}{l}A L S 2,4,5,6,7 \\
S A P 5,6,9,10\end{array}$ \\
\hline 47 & Sputum & 53 & $\mathrm{~F}$ & $43.80 \%$ & 3.2 & Localized & Low & $\begin{array}{c}A L S 1,2,3,4,5,6,7,8 \\
S A P 4,5,6,9,10, E A P 1\end{array}$ \\
\hline 67 & Sputum & 44 & M & $33.76 \%$ & 5.1 & Diffusion & Low & $\begin{array}{l}A L S \text { 3, 5, 7, } \\
\text { SAP 6, 9, } 10\end{array}$ \\
\hline 29 & Sputum & 51 & $\mathrm{M}$ & $41.17 \%$ & 3.5 & Localized & None & $\begin{array}{c}A L S 1,2,3,4,5,6,7,8 \\
S A P 2,5,6,9,10, E A P 1\end{array}$ \\
\hline 1166 & Sputum & 60 & $\mathrm{M}$ & $48.27 \%$ & 5.6 & Diffusion & low & $\begin{array}{c}A L S 2,3,4,5,6,7, S A P 2 \\
4,5,9,10\end{array}$ \\
\hline 149 & Sputum & 33 & $\mathrm{~F}$ & $46.92 \%$ & 4.8 & Diffusion & low & $\begin{array}{c}A L S 1,2,3,4,5,6,7, S A P \\
2,5,6,9,10\end{array}$ \\
\hline 58 & Sputum & 31 & $\mathrm{~F}$ & $44.71 \%$ & 2.62 & localized & low & $\begin{array}{c}A L S 1,4,5,6,7,8, S A P 4, \\
5,6,9,10\end{array}$ \\
\hline 81 & Sputum & 64 & $\mathrm{~F}$ & $45.30 \%$ & 3.76 & localized & low & $\begin{array}{l}A L S \text { 1, 2, 3, 4, 6, } \\
\text { SAP 4, 5, 6, 9, } 10\end{array}$ \\
\hline 103 & Sputum & 50 & $\mathrm{~F}$ & $44.64 \%$ & 3.17 & localized & low & $\begin{array}{c}A L S 1,2,3,4,5,6,7,8 \\
S A P 4,5,9,10\end{array}$ \\
\hline 105 & Sputum & 44 & M & $47.29 \%$ & 5.3 & localized & low & $\begin{array}{c}A L S 3,7,8 \\
\text { SAP } 9\end{array}$ \\
\hline 2693 & Sputum & 41 & $\mathrm{~F}$ & $40.0 \%$ & 3.4 & Diffusion & Low & $\begin{array}{c}A L S 1,2,4,5,6,7,8, S A P \\
5,9,\end{array}$ \\
\hline 255 & Sputum & 37 & $\mathrm{M}$ & $\begin{array}{c}82.79 \\
\%\end{array}$ & 5.92 & $\begin{array}{l}\text { Aggrega- } \\
\text { tive }\end{array}$ & Low & $\begin{array}{c}A L S 2,3,4,5,6,7,8, S A P \\
4,5,9,10, E A P 1\end{array}$ \\
\hline
\end{tabular}


Continued on page 6

\begin{tabular}{|c|c|c|c|c|c|c|c|c|}
\hline $\begin{array}{l}\text { C. albicans } \\
\text { strain code }\end{array}$ & $\begin{array}{l}\text { Isolation } \\
\text { source }\end{array}$ & Age & Sex & AIn & $\begin{array}{l}\text { Average no. } \\
\text { of yeast cells/ } \\
\text { HeLa cell }\end{array}$ & $\begin{array}{l}\text { Adher- } \\
\text { ence } \\
\text { pattern }\end{array}$ & $\begin{array}{c}\text { Biofilm to } \\
\text { inert sub- } \\
\text { stratum }\end{array}$ & Adherece genes profile \\
\hline 1776 & $\begin{array}{l}\text { Bronchi- } \\
\text { al Secre- } \\
\text { tions }\end{array}$ & 64 & $\mathrm{~F}$ & $28.30 \%$ & 2.14 & Localized & Low & $\begin{array}{c}A L S 2,3,5,6,8 \\
S A P 6,9,10\end{array}$ \\
\hline 1135 & $\begin{array}{l}\text { Bronchi- } \\
\text { al Secre- } \\
\text { tions }\end{array}$ & 51 & $\mathrm{M}$ & $30.44 \%$ & 2 & Diffusion & Low & $\begin{array}{c}A L S \text { 1, 3, 5, 6, } \\
S A P 2,5,6,9,10,\end{array}$ \\
\hline 373 & $\begin{array}{l}\text { Bronchi- } \\
\text { al Secre- } \\
\text { tions }\end{array}$ & 62 & $\mathrm{~F}$ & $68.10 \%$ & 6 & $\begin{array}{l}\text { Aggrega- } \\
\text { tive }\end{array}$ & Low & $\begin{array}{c}A L S 2,3,4,6, \\
S A P 9,10\end{array}$ \\
\hline 305 & $\begin{array}{l}\text { Bronchi- } \\
\text { al Secre- } \\
\text { tions }\end{array}$ & 86 & $\mathrm{~F}$ & $68.50 \%$ & 6.8 & $\begin{array}{l}\text { Aggrega- } \\
\text { tive }\end{array}$ & Low & $\begin{array}{c}A L S 1,5,6,8, \\
\text { SAP } 6\end{array}$ \\
\hline 1995 & $\begin{array}{l}\text { Bronchi- } \\
\text { al Secre- } \\
\text { tions }\end{array}$ & 60 & $\mathrm{~F}$ & $82.09 \%$ & 8.62 & $\begin{array}{l}\text { Aggrega- } \\
\text { tive }\end{array}$ & Low & $\begin{array}{l}A L S 1,2,3,4,5,6,7,8 \\
\quad S A P 9,10, E A P 1\end{array}$ \\
\hline 1942 & $\begin{array}{l}\text { Bronchi- } \\
\text { al Secre- } \\
\text { tions }\end{array}$ & 64 & $\mathrm{M}$ & $71.81 \%$ & 7.9 & $\begin{array}{l}\text { Aggrega- } \\
\text { tive }\end{array}$ & Low & $\begin{array}{c}A L S \text { 1, 3, 4, 5,6, } \\
\text { SAP 6, 9, } 10\end{array}$ \\
\hline 1946 & $\begin{array}{l}\text { Bronchi- } \\
\text { al Secre- } \\
\text { tions }\end{array}$ & 64 & $\mathrm{~F}$ & $69.04 \%$ & 5.8 & $\begin{array}{l}\text { Aggrega- } \\
\text { tive }\end{array}$ & Low & $\begin{array}{l}A L S \text { 5, } 6, \\
\text { SAP 9, } 10\end{array}$ \\
\hline 1935 & $\begin{array}{l}\text { Bronchi- } \\
\text { al Secre- } \\
\text { tions }\end{array}$ & 59 & $\mathrm{M}$ & $75.10 \%$ & 7.18 & $\begin{array}{l}\text { Aggrega- } \\
\text { tive }\end{array}$ & Low & $\begin{array}{c}A L S \text { 3, 5, 6, 7,8 } \\
\text { SAP 6, } 9\end{array}$ \\
\hline 1675 & $\begin{array}{l}\text { Bronchi- } \\
\text { al Secre- } \\
\text { tions }\end{array}$ & 25 & $\mathrm{M}$ & $81.67 \%$ & 6.15 & $\begin{array}{l}\text { Aggrega- } \\
\text { tive }\end{array}$ & Low & $\begin{array}{l}A L S 1,2,3,4,5,6,7,8 \\
S A P 4,5,6,9,10, E A P 1\end{array}$ \\
\hline 1676 & $\begin{array}{l}\text { Bronchi- } \\
\text { al Secre- } \\
\text { tions }\end{array}$ & 31 & M & $74.42 \%$ & 4.57 & $\begin{array}{l}\text { Aggrega- } \\
\text { tive }\end{array}$ & Low & 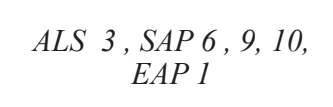 \\
\hline
\end{tabular}

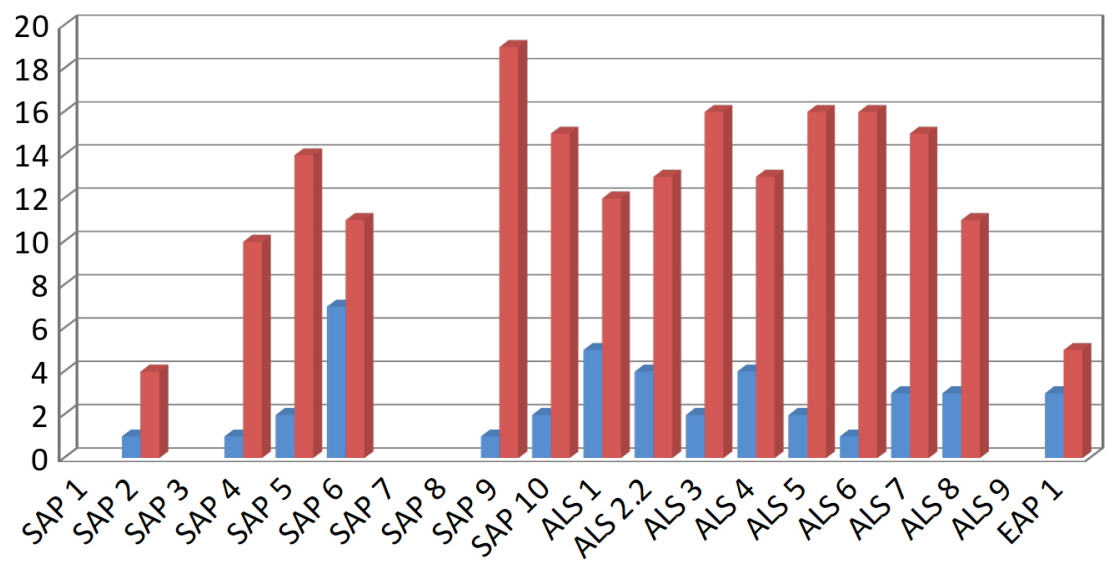

Bronchial Secretions Sputum

Fig. 3. Distribution of $C$. albicans adhesion genes in strains isolated from sputum and bronchial secretions 
substrate (Fig. 2). Overall, isolates from the upper respiratory tract were higher biofilm producers, this feature being correlated with a high AIn (Fig. 2 insertion). Previous research studies have shown that strains isolated from invasive infections tend to produce biofilms more intensely in comparison with isolates from non-invasive infections (42).

Our results indicated a generally non-statistically significant $(P>0.05)$ correlation between the presence of $A L S$ and $S A P$ genes and AIn for $C$. albicans isolates that were isolated from sputum and bronchial secretions (Fig. 3, Table 1). There were, however, some exceptions. The $A L S 3$ gene presence in strains isolated from sputum and of $S A P 2$ in those isolated from bronchial secretions were significantly correlated with a high AIn $(P<0.05)$. However, the only significant associations between adherence genes and biofilm formation capacity were $A L S 1$ in tracheal and $A L S 8$ in sputum isolates $(P<0.05)$. The $A L S 3$ polymorphism led to variable biofilm production in different species isolated from sources such as blood, vulvo-vaginal secretions, and urine cultures (43).

\section{Discussion}

Fungal infections due to $C$. albicans in critically ill hospitalized patients are a significant cause of morbidity and mortality worldwide. Peterson et al. (44) observed that $55 \%$ of hospitalized patients carried yeasts in their saliva. More specifically, Candida spp. strains were found in between $47-87 \%$ of in patients with advanced cancer, and in the oral mucosa of up to $80 \%$ of diabetic patients (40). In our study, $C$. albicans strains that are isolated from patients hospitalized for cardiovascular surgery were predominantly from bronchial secretions $(65 \%)$.

The ability to colonize host tissues is considered one of the most significant factors for C. albi- cans virulence (41). Candida spp. adherence to human tissues permits the fungus to reach the minimum infective threshold and colonize a specific niche environment. Candida has a specific feature which enables it to survive and develop within different circumstances of healthy human body and then to invade tissues. Thus, the colonized area provides the essential ground for Candida development, proliferation, invasion, and dissemination (45). However, any modification in the host immune system, or host environment, can lead to the switching $C$. albicans into a pathogenic form and then able of causing biofilm-associated infections were also noted to play a significant role in perpetuating these infections since these structures could allow the yeast to adhere to medical devices. However, there is limited information available as to the molecular mechanisms that mediate C. albicans adhesion to materials or mammalian cells. The relationship between the phenotype of a strain (e.g., the ability to adhere and/or form a biofilm) and genotype is also barely known. Our findings indicate that $C$. albicans isolated from bronchial secretions adhered better to cellular and inert substrata compared to sputum-isolated strains. These bronchial-derived strains also had a specific adherence gene profile. It has been previously described that $A L S$ genes play an important role in $C$. albicans adherence and biofilm formation and growth, the $A L S 1$ protein product being associated with the capacity of Candida spp. strains to adhere to endothelial cells and form biofilms (46). We found that the presence of $A L S 3, A L S 5, A L S 6$, and $S A P 9$ genes is correlated with $C$. albicans adhesion to polystyrene and human epithelial cells. The SAP9 and ALS3 adherence genes contribute to the overall virulence of C. albicans strains, being usually expressed in virulent strains isolated from symptomatic infections and enable attachment to cellular and inert substrata. Our results differed compared with a previous study (47) in which the authors report- 
ed that other genes which were not identified in our study, respectively $A L S 1$ and $A L S 9$, were detected in the clinical isolates. In our study, 90\% of the analyzed strains were $S A P 9$ positive, the next most prevalent gene present in the strains being SAP5. We noticed that C. albicans isolates that expressed $S A P 9$ were more virulent in comparison with isolates that expressed SAP5 and $S A P 6$, and then the remaining analyzed genes, therefore $S A P 9$ plays a significant role in biofilm development, probably through favoring yeast to hyphal transition, as a response to environmental stimuli via a cyclic adenosine monophosphate(cAMP) dependent signaling pathway (48). Hyphal development contributes to Candida invasion of epithelial cells and leads to host cell damage.

\section{Conclusions}

Our work describes the relationship between different phenotypic features that are related to cell adherence and biofilm development and the presence of adherence genes. The analyzed $C$. albicans strains were isolated from the respiratory tract of patients undergoing cardiovascular surgery. The isolates were able to adhere to cellular and inert substrata and to form biofilms. The investigation of the adherence gene profiles in our C. albicans isolate revealed the presence of several $A L S$ genes, correlated with the respective isolates ability to colonize the cellular substratum. The isolates expressing the $S A P 9$ were the most virulent, likely because $S A P 9$ favors the yeast to hyphal transition. Overall, our study demonstrates that the PCR detection of adherence genes could represent a simple and cost effective tool for the prediction of the virulence capacity and pathogenic potential of different $C$ albicans clinical isolates, replacing the more expensive and time-consuming phenotypic assays of adherence and biofilm development capacity.

\section{Acknowledgments}

We gratefully acknowledge the support of the staff in Department of Microbiology- Faculty of Biology and Research Institute of the University of Bucharest and the financial support of the Government of Iraq.

\section{Author Contributions}

OS, IG, GGP conceived and designed the experiments; IG, OS, AMH, LMD, IA, OA and DA performed the experiments; OB provided the $C$. albicans strains; IG, LMD, AMH and CC analyzed the data; OS, IG and MCC wrote and corrected the paper.

\section{Abbreviations}

ALS - Agglutinin Like Sequences

SAP - Secreted Aspartyl Proteinase

CSH - Cell Surface Hydrophobicity

AIn - Adherence Index

EAP - Extracellular Adhesion Proteins

\section{References}

1. Calderone RA, Fonzi WA. Virulence factors of Candida albicans. Trends Microbiol. 2001;9(7):327-35. DOI: 10.1016/S0966-842X(01)02094-7

2. Cirpaciu D, Goanţă CM, Tusaliu M, Curutiu C, Budu V. Microbial etiology of acute otitis externa-a one year study. Rom Biotech Lett. 2017;22(1):12316.

3. Fanello S, Bouchara J, Sauteron M, Delbos V, Parot E, Marot-Leblond A, et al. Predictive value of oral colonization by Candida yeasts for the onset of a nosocomial infection in elderly hospitalized patients. J Med Microbiol. 2006;55(2):223-8. DOI: 10.1099/jmm.0.46155-0

4. Wisplinghoff $\mathrm{H}$, Bischoff $\mathrm{T}$, Tallent SM, Seifert H, Wenzel RP, Edmond MB. Nosocomial bloodstream infections in US hospitals: analysis of 24,179 cases from a prospective nationwide surveillance study. Clin Infect Dis. 2004;39(3):309-17. DOI: 10.1086/421946

5. Grimoud AM, Marty N, Bocquet H, Andrieu S, Lodter JP, Chabanon G. Colonization of the oral cavity by Candida species: risk factors in long-term geriatric 
care. J Oral Sci. 2003;45(1):51-5. DOI: 10.2334/josnusd. 45.51

6. Dongari-Bagtzoglou A, Dwivedi P, Ioannidou E, Shaqman M, Hull D, Burleson J. Oral Candida infection and colonization in solid organ transplant recipients. Oral Microbiol Immun. 2009;24(3):249-54. DOI: 10.1111/j.1399-302X.2009.00505.x

7. Budtz-Jörgensen E, Stenderup A, Grabowski M. An epidemiologic study of yeasts in elderly denture wearers. Community Dent Oral Epidemiol. 1975;3(3):115-9. DOI: 10.1111/j.1600-0528.1975.tb00291.x

8. Shimizu C, Kuriyama T, Williams DW, Karasawa T, Inoue K, Nakagawa $\mathrm{K}$, et al. Association of oral yeast carriage with specific host factors and altered mouth sensation. Oral Surg Oral Med Oral Patholo Oral Radiol Endod. 2008;105(4):445-51. DOI: 10.1016/j. tripleo.2007.11.030

9. Yano A, Abe A, Aizawa F, Yamada H, Minami K, Matsui $\mathrm{M}$, et al. The effect of eating sea cucumber jelly on Candida load in the oral cavity of elderly individuals in a nursing home. Mar Drugs. 2013;11(12):4993-5007. DOI: $10.3390 / \mathrm{md} 11124993$

10. Cuéllar-Cruz M, López-Romero E, Villagómez-Castro JC, Ruiz-Baca E. Candida species: new insights into biofilm formation. Future Microbiol. 2012;7(6):75571. DOI: $10.2217 / \mathrm{fmb} .12 .48$

11. Finkel JS, Mitchell AP. Genetic control of Candida albicans biofilm development. Nat Rev Microbiol. 2011;9(2):109. DOI: 10.1038/nrmicro2475

12. Harriott MM, Noverr MC. Importance of Candidabacterial polymicrobial biofilms in disease. Trends Microbiol. 2011;19(11):557-63. DOI: 10.1016/j. tim.2011.07.004

13. Mayer F, Wilson D, Hube B. Candida albicans pathogenicity mechanisms. Virulence 4: 119-128. 2013. DOI: $10.4161 /$ viru.22913

14. Georgescu M, Vrinceanu D, Radulescu L, Tusaliu M, Martu C, Curutiu C, et al. Microbial biofilms and implantable hearing aids. Rom Biotech Lette. 2017;22(4):12681-6.

15. Ramage G, Rajendran R, Sherry L, Williams C. Fungal biofilm resistance. Int J Microbiol. 2012;2012.

16. Mathé L, Van Dijck P. Recent insights into Candida albicans biofilm resistance mechanisms. Curr Genet. 2013;59(4):251-64. DOI: 10.1007/s00294-013-0400-3

17. Baillie GS, Douglas LI. Role of dimorphism in the development of Candida albicans biofilms. J Med Microbiol. 1999;48(7):671-9. DOI: 10.1099/00222615-48-7-671
18. Ramage G, VandeWalle K, López-Ribot JL, Wickes BL. The filamentation pathway controlled by the Efg1 regulator protein is required for normal biofilm formation and development in Candida albicans. FEMS Microbiol lett. 2002;214(1):95-100. DOI: 10.1111/j.15746968.2002.tb11330.x

19. Richard ML, Nobile CJ, Bruno VM, Mitchell AP. Candida albicans biofilm-defective mutants. Eukaryot Cell. 2005;4(8):1493-502. DOI: 10.1128/EC.4.8.14931502.2005

20. Bonhomme J, d'Enfert C. Candida albicans biofilms: building a heterogeneous, drug-tolerant environment. Curr Opin Microbiol. 2013;16(4):398-403. DOI: 10.1016/j.mib.2013.03.007

21. Nobile CJ, Mitchell AP. Regulation of cell-surface genes and biofilm formation by the C. albicans transcription factor Bcr1p. Curr Biol. 2005;15(12):1150-5. DOI: 10.1016/j.cub.2005.05.047

22. Nobile CJ, Andes DR, Nett JE, Smith Jr FJ, Yue F, Phan Q-T, et al. Critical role of Bcr1-dependent adhesins in C. albicans biofilm formation in vitro and in vivo. PLoS Pathog. 2006;2(7):e63. DOI: 10.1371/journal. ppat.0020063

23. Nobile CJ, Nett JE, Andes DR, Mitchell AP. Function of Candida albicans adhesin Hwp1 in biofilm formation. Eukaryot Cell. 2006;5(10):1604-10. DOI: 10.1128/ EC.00194-06

24. Ghannoum M, Elteen KA. Correlative relationship between proteinase production, adherence and pathogenicity of various strains of Candida albicans. J Med Vet Mycol. 1986;24(5):407-13. DOI: $10.1080 / 02681218680000621$

25. Abu-Elteen KH, Elkarmi AZ, Hamad M. Characterization of phenotype-based pathogenic determinants of various Candida albicans strains in Jordan. Jap J Infect Dis. 2001;54(6):229-36.

26. Rosa EAR, Rached RN, Ignácio SA, Rosa RT, da Silva WJ, Yau JYY, et al. Phenotypic evaluation of the effect of anaerobiosis on some virulence attributes of Candida albicans. J Med Microbiol. 2008;57(10):1277-81. DOI: 10.1099/jmm.0.2008/001107-0

27. Pichová I, Pavličková L, Dostál J, Dolejší E, HruškováHeidingsfeldová $\mathrm{O}$, Weber J, et al. Secreted aspartic proteases of Candida albicans, Candida tropicalis, Candida parapsilosis and Candida lusitaniae: inhibition with peptidomimetic inhibitors. Eur J Biochem. 2001;268(9):2669-77. DOI: 10.1046/j.14321327.2001.02152.x 
28. Borg M, Rüchel R. Expression of extracellular acid proteinase by proteolytic Candida spp. during experimental infection of oral mucosa. Infect Immun. 1988;56(3):626-31.

29. El-Maghrabi E, Dixon D, Burnett J. Characterization of Candida albicans epidermolytic proteases and their role in yeast-cell adherence to keratinocytes. Clin Exp Dermatol. 1990;15(3):183-91. DOI: 10.1111/j.13652230.1990.tb02069.x

30. Ollert M, Söhnchen R, Korting H, Ollert U, Bräutigam $\mathrm{S}$, Bräutigam W. Mechanisms of adherence of Candida albicans to cultured human epidermal keratinocytes. Infect Immun. 1993;61(11):4560-8.

31. Li F, Palecek SP. EAP1, a Candida albicans gene involved in binding human epithelial cells. Eukaryot Cell. 2003;2(6):1266-73. DOI: 10.1128/EC.2.6.12661273.2003

32. Hazen K, Glee P. Cell surface hydrophobicity and medically important fungi. Curr Top Med Mycol. 1995;6:1.

33. Hazen KC, Wu JG, Masuoka J. Comparison of the hydrophobic properties of Candida albicans and Candida dubliniensis. Infect Immun. 2001;69(2):779-86. DOI: 10.1128/IAI.69.2.779-786.2001

34. Telcian A, Mohammed DH, Chifiriuc M, Bleotu C, Holban A, Curutiu C, et al. Assessment of the anti-biofilm activity and biocompatibility of novel PE and PVC polymers. Rom Biotech Lett. 2017;22(5):12997.

35. Stan T, Teodor ED, Gatea F, Chifiriuc C, Lazăr V. Antioxidant and antifungal activity of Romanian propolis. Rom Biotech Lett. 2017;22(6):12116-13124.

36. Melo AS, Bizerra FC, Freymüller E, Arthington-Skaggs BA, Colombo AL. Biofilm production and evaluation of antifungal susceptibility amongst clinical Candida spp. isolates, including strains of the Candida parapsilosis complex. Med Mycol. 2011;49(3):253-62. DOI: 10.3109/13693786.2010.530032

37. Hassan A, Usman J, Kaleem F, Omair M, Khalid A, Iqbal M. Evaluation of different detection methods of biofilm formation in the clinical isolates. Braz $\mathrm{J}$ Infect Dis. 2011;15(4):305-11. DOI: 10.1016/S14138670(11)70197-0

38. Konkel ME, Joens LA. Adhesion to and invasion of HEp-2 cells by Campylobacter spp. Infect Immun. 1989;57(10):2984-90.

39. Zhang Y, Zhang S, Liu X, Wen H, Wang M. A simple method of genomic DNA extraction suitable for analysis of bulk fungal strains. Lett Appl Mi- crobiol. 2010;51(1):114-8. DOI: $\quad 10.1111 / \mathrm{j} .1472-$ 765X.2010.02867.x

40. Bruder-Nascimento A, Camargo CH, Mondelli AL, Sugizaki MF, Sadatsune T, Bagagli E. Candida species biofilm and Candida albicans ALS3 polymorphisms in clinical isolates. Braz J Microbiol. 2014;45(4):1371-7. DOI: $10.1590 / \mathrm{S} 1517-83822014000400030$

41. Soll DR. The ins and outs of DNA fingerprinting the infectious fungi. Clin Microbiol Rev. 2000;13(2):33270. DOI: 10.1128/CMR.13.2.332

42. Samaranayake Y, Dassanayake R, Cheung B, Jayatilake J, Yeung K, Yau J, et al. Differential phospholipase gene expression by Candida albicans in artificial media and cultured human oral epithelium. APMIS. 2006;114(12):857-66. DOI: 10.1111/j.1600-0463.2006. apm_479.x

43. Cho T, Hamatake H, Kaminishi H, Hagihara Y, Watanabe $\mathrm{K}$. The relationship between cyclic adenosine 3', 5'-monophosphate and morphology in exponential phase Candida albicans. J Med Vet Mycol. 1992;30(1):35-42. DOI: 10.1080/02681219280000051

44. Ogasawara A, Odahara K, Toume M, Watanabe T, Mikami T, Matsumoto T. Change in the respiration system of Candida albicans in the lag and log growth phase. Biol Pharm Bull. 2006;29(3):448-50. DOI: 10.1248/ bpb. 29.448

45. Abad-Zapatero C, Goldman R, Muchmore SW, Hutchins C, Stewart K, Navaza J, et al. Structure of a secreted aspartic protease from $C$. albicans complexed with a potent inhibitor: implications for the design of antifungal agents. Protein Sci. 1996;5(4):640-52. DOI: 10.1002/pro.5560050408

46. O'Connor L, Lahiff S, Casey F, Glennon M, Cormican M, Maher M. Quantification of ALS1 gene expression in Candida albicans biofilms by RT-PCR using hybridisation probes on the LightCycler ${ }^{\mathrm{TM}}$. Mol Cell Probes. 2005;19(3):153-62. DOI: 10.1016/j.mcp.2004.10.007

47. Cheng G, Wozniak K, Wallig MA, Fidel PL, Trupin SR, Hoyer LL. Comparison between Candida albicans agglutinin-like sequence gene expression patterns in human clinical specimens and models of vaginal candidiasis. Infect Immun. 2005;73(3):1656-63. DOI: 10.1128/IAI.73.3.1656-1663.2005

48. Wang Y. Fungal adenylyl cyclase acts as a signal sensor and integrator and plays a central role in interaction with bacteria. PLoS Pathog. 2013;9(10):e1003612. DOI: $10.1371 /$ journal.ppat.1003612 